$1-20-2003$

\title{
Light and Color in the Open Air: Introduction to the Feature Issue
}

Charles L. Adler

James A. Lock

Cleveland State University, j.lock@csuohio.edu

Follow this and additional works at: https://engagedscholarship.csuohio.edu/sciphysics_facpub

Part of the Physics Commons

How does access to this work benefit you? Let us know!

\section{Publisher's Statement}

This paper was published in Applied Optics and is made available as an electronic reprint with the permission of OSA. The paper can be found at the following URL on the OSA website: http://www.opticsinfobase.org/ao/abstract.cfm?URI=ao-42-3-307. Systematic or multiple reproduction or distribution to multiple locations via electronic or other means is prohibited and is subject to penalties under law.

\section{Original Citation}

Adler, Charles L. and James A. Lock. "Light and Color in the Open Air: Introduction to the Feature Issue." Applied Optics 42 (2003): 307-308.

\section{Repository Citation}

Adler, Charles L. and Lock, James A., "Light and Color in the Open Air: Introduction to the Feature Issue" (2003). Physics Faculty Publications. 119.

https://engagedscholarship.csuohio.edu/sciphysics_facpub/119

This Editorial is brought to you for free and open access by the Physics Department at EngagedScholarship@CSU. It has been accepted for inclusion in Physics Faculty Publications by an authorized administrator of EngagedScholarship@CSU. For more information, please contact library.es@csuohio.edu. 


\title{
Light and color in the open air: introduction to the feature issue
}

\author{
Charles L. Adler and James A. Lock
}

\begin{abstract}
This special feature of Applied Optics reports the results of new experimental and theoretical research concerning a number of naked-eye optical phenomena, including ice-crystal halo displays, mirages, rainbows, glories, optical caustics, clear-sky phenomena, cloud coronas, cloud iridescence, and the extinction of skylight. (C) 2003 Optical Society of America

OCIS codes: $010.0010,280.0280,290.0290,330.0330$.
\end{abstract}

There are all kinds of interesting questions that come from a knowledge of science, which only adds to the excitement and mystery and awe of a flower.

-Richard Feynman ${ }^{1}$

A young child is first introduced to science by observing his or her natural surroundings. These observations impress on the child both a sense of excitement at the diversity in nature and a curiosity as to why the world around us is the way it is. As a child grows older and becomes capable of understanding greater abstraction, he or she learns about other worlds not directly accessible with one's senses, the worlds of the very small, the very large, and the very far away. These other worlds are explored with one's senses amplified and extended by a vast array of scientific instruments, and seeing the myriad of diverse phenomena occurring in these other worlds gives one a sense of awe at the range and scope of science.

For well over a century now, the frontiers of science have grown increasingly further removed from our everyday experience and observation of the natural world around us. As a result, it has become increasingly difficult for scientists to convey the nature of their discoveries and their enthusiasm to nonscientists. But many scientists continue to feel the same excitement and sense of mystery and awe at the naked-eye phenomena in the world around them as they did when they first saw these phenomena as

Charles L. Adler (cladler@smcm.edu) is with the Department of Physics, St. Mary's College of Maryland, St. Mary's City, Maryland 20686. James A. Lock (j.lock@csuohio.edu) is with the Department of Physics, Cleveland State University, Cleveland, Ohio 44115.

0003-6935/03/030307-02\$15.00/0

(C) 2003 Optical Society of America children, and they rejoice when they are lucky enough to see a rare phenomenon that they have not seen before but have only heard about from others.

This special issue of Applied Optics features new findings and the understanding derived from these findings concerning a number of naked-eye optical phenomena that can be seen by anyone willing to take the time to gaze skyward and look. When our eyes view the world around us, we see light emanating from our surroundings. The light originates from distant objects and is distorted by the intervening atmosphere; it is scattered into different directions by ice crystals, water droplets, or cloud particles in the air; and objects such as the sky and clouds take on different colors when viewed under different circumstances. The richness and depth of these naked-eye optical phenomena is evidenced by the fact that in spite of all that has been learned about them by previous generations of scientists, new aspects of the phenomena, hitherto unsuspected or unexplained, become accessible by use of new experimental techniques and are more powerfully analyzed with modern mathematical and computational methods.

The title of this special feature of Applied Optics is taken from the book of the same name ${ }^{2}$ by Marcel Minnaert, who pioneered the modern scientific study of naked-eye optical phenomena. Many of the findings reported here were first presented at the Seventh Topical Meeting on Meteorological Optics ${ }^{3}$ held in Boulder, Colorado, on 5-8 June 2001 and sponsored by the University Corporation for Atmospheric Research and the American Meteorological Society. 
A number of feature issues of Applied Optics and the Journal of the Optical Society of America dedicated to naked-eye optical phenomena and meteorological optics have previously been published by the Optical Society of America and are enumerated in Ref. 4.

The feature editors thank the Optical Society of America for their support of this feature and for providing the authors the opportunity to display many of the phenomena described in this issue in color. We particularly wish to thank the staff of the Optical Society for coordinating the semi-infinite number of details required for the production of this special feature.

\section{References and Notes}

1. R. P. Feynman, What Do You Care What Other People Think? (Bantam, New York, 1989), p. 11.
2. M. Minnaert, Light and Color in the Open Air (Dover, New York, 1954). This book has been republished as M. Minnaert, Light and Color in the Outdoors (Springer-Verlag, New York, 1993).

3. Previous Topical Meetings on Meteorological Optics were held in Keystone, Colorado, August 1978; Incline Village, Nevada, January 1983; and Honolulu, Hawaii, April 1986. Previous Topical Meetings on Light and Color in the Open Air whose principal focus was meteorological optics were held in Washington, D.C., July 1990; University Park, Pennsylvania, June 1993; and Santa Fe, New Mexico, February 1997.

4. Previous feature issues on naked-eye optical phenomena and meteorological optics associated with the meetings enumerated in Ref. 3 are J. Opt. Soc. Am. 69, 1051-1198 (1979); J. Opt. Soc. Am. 73, 1622-1664 (1983); J. Opt. Soc. Am. A 4, 558-620 (1987); Appl. Opt. 30, 3381-3552 (1991); Appl. Opt. 33, 45354760; and Appl. Opt. 37, 1425-1588 (1998). 